\title{
Bumiputera-Controlled Companies: Performance Evaluation Using A Non-Parametric Approach
}

\author{
Maran Marimuthu \\ Department of Economics \\ Faculty of Accountancy and Management, Tunku Abdul Rahman University \\ Bandar Sungai Long Campus, 43000 Kajang, Selangor DE \\ Tel: 60-3-9019-4722 (0) E-mail: maran@utar.edu.my
}

\begin{abstract}
This study examines the effects of crisis and post-crisis periods on the performance of Bumiputera-controlled companies in Malaysia. A sample of 33 Bumiputera-controlled companies listed on Bursa Malaysia is considered over the period 1996 to 2005 . ROE is used as a performance measure and Wilcoxon Signed Ranks Test is used to justify our argument. Results indicate that Bumiputera-controlled companies suffered in both short run and long run due to the financial crisis.
\end{abstract}

Keywords: Bumiputera companies, Crisis, Performance

\section{Introduction}

The drastic changes in recent decades in the Malaysian business scene arising from international competition, globalization, and rapid changes in technology have forced many Malaysian companies to create new products, services, processes and systems that can compete in the ever changing business environment. The Malaysian industries are becoming more competitive in the global market and the number of new entries in the market has put enormous pressure on management revamps in this highly competitive market. Controlling power will be based on the equity ownership of the company. In other words, the ownership and control of the company will be determined by the percentage of shares and equity being hold in the company. In Malaysia, controlling power can be segregated by race or ethnic group. Hence, there will be Malay or Bumiputera-controlled companies, Chinese-controlled companies, Indian-controlled companies, family-owned companies and so and so forth. Meanwhile, a company can also be controlled by the state or federal government through their investment arms. They are called Government-Link companies (GLCs) or state-owned enterprises (SOEs). It should be pointed out here that GLCs are however, not regarded as Bumiputera-controlled companies though some ambiguity exists between the two.

\section{Definition of Bumiputera}

Bumiputera or Bumiputra is from a Sanskrit word Bhumiputra; in which being translated literally means the "son of the Earth". In Malay, it is being translated literally as "princes of the Earth". This arise from the official definition which is widely used in Malaysia whereby it taking up ethnic Malays as well as other indigenous ethnic groups such as the Orang Asli in Peninsular Malaysia and the tribal people in Sabah and Sarawak(Note 1). In Malaysia, by convention, it is generally considered that all Malays are Bumiputeras.

\section{Definition of Bumiputera-Controlled Companies (BCCs)}

A company that is regarded as 'Bumiputera-controlled company' when either one of the following two criteria is being satisfied besides a compulsory 30 per cent equity ownership by bumiputeras in any listed company in Malaysia. Firstly, more than 50 percent of the equity is owned by Bumiputera shareholders. Second, at least 35 percent of its equity is owned by an individual Bumiputera shareholder (Note 2). In addition, there are no other non-Bumiputera groups holding more than 10 percent of the voting power of the company. In other words is that the identifiable non-Bumiputera groups should not own more than 24 percent of the voting power of the company.

The shareholding of the Bumiputera group is not associated directly or indirectly with any non-Bumiputera group. The Bumiputera group is the rightful owner and each Bumiputera party is capable of exercising the voting power attached to his/her/its shareholding free of any influence. The Chairman, Chief Executive officer or Managing Director and at least 51 percent of the company's board members are Bumiputera individuals and lastly is that at least 51 percent of the management, professional and supervisory staff comprises Bumiputera individuals. 


\section{Issues}

Since the financial crisis, BCCs were left vulnerable to some uncertainty in the financial environment. BCCs were unable to get off the ground after the currency crisis (Note 3) as compared to foreign companies and thus, Bumiputera-controlled companies were said to have continued experiencing difficulties. There were many comments given on the performance and sustainability of the Malaysian companies as whole, and BCCs in particular. Much of the discussion was very much connected to their performance during the post crisis period. In view of this, there is a need to further explore the behaviour of BCCs with regard to their financial performance. The understanding of their performance should be viewed in both short and long run. With this, more insightful information could be derived from the study. Here are a few studies that look into the performance of companies on a short run basis after the financial crisis. Yatim, Pamela and Peter (2006) look into the performance of Bumiputera-controlled firms in paying higher audit fees. Viani (2004) look into the operating performance of companies under private and state control.

\section{Objective of the study}

The objective of this study is to examine the performance of Bumiputera-controlled Companies on a short term and long term periodical basis over a period of 10 years. Thus, this study seeks to report the short term performance (by every year) and long term performance (with intervals of three, five and ten years) of the Bumiputera-controlled companies.

\section{Related Studies}

How et.al (2007) tested on the pricing of IPO shares is related to share allocation in Malaysia. The result of this study is motivated by the prevalence Bumiputera ownerships in Malaysia. Dev, George, and Ariff (2006) investigated that the impact of government initial public offering (IPO) regulating intending on promoting public policy which mandated that at least 30 percent of any new shares on an IPO offer be sold to the indigenous Bumiputera population or to mutual funds owned by them. The study examined the short-run and long-run under pricing of Malaysian IPOs and found that Malaysian IPOs are highly under priced compared to IPOs in developing countries, creating a market microstructure effect. It also confirmed that the Malaysian government's regulatory intervention in spite of noble public policy intentions appeared to be the significant factor for the emergence of an average first day under pricing increase of Malaysian IPOs by 61 percent during the period after the regulatory economic policy was instituted.

The creation of Bumiputera Commercial and Industrial Community (BCIC) has become a great boost for many Bumiputeras, particularly the food-processing industry (Shahadan, 2001). Yatim, Kent and Clarkson (2006) revealed that the Bumiputera-controlled firms improved internal corporate governance practices compared to their non-Bumiputera counterparts. Bumiputera-controlled firms pay lower external audit fees because their internal governance structures are stronger relative to their non-Bumiputera counterparts. The Bumiputera firms practice more favourable corporate governance practices compared to their non-Bumiputera counterparts.

Quite a number of studies were done on short run and long run performance evaluation. In addition, ROA and ROE seemed the measures used for performance evaluation. The use of short period and long periods seemed to be quite common for many researchers (using $\mathrm{ROE}$ as a performance measure) with regard to performance evaluation (Westhead and Howorth, 2006; Meuse, Bergmann, Vanderheiden and Roraff, 2004; Bhagat and Black, 2002 and Viani, 2004). In another study, Hou and Chuang (2007) used a ten year period (1996 - 2005) to understand corporate performance. Other related studies indicating the use of long run and short run approaches as well as the consideration of ROE or ROA as a measure to measure shareholder wealth included Bris, Koskinen and Pons (2004), Clayton and Qian (2004), Rahman and Haniffa (2005), Wet and Toit (2007), Sun and Tong (2002), Murray (1989) and Hsu and Boggs (2003).

\section{Data collection, Methods and Measures}

First about 186 listed companies were first identified, however, not many companies could be considered for this study as the availability of data was the most crucial factor. The criteria adopted in selecting Bumiputera-Controlled companies have been clarified in the earlier part (part 3). The sample size was finally concluded with 33 companies listed on Bursa Malaysia over a period of 10 years from 1996-2005 (Appendix 1). All the financial data were obtained from Exodus, Bursa Malaysia, and annual reports of the companies. Wilcoxon Signed Ranks Test was adopted to detect significant differences between two different periods.

The details of the measures used in this study are as follows:

Return on assets $($ ROA $)=$ Net income $/$ Total assets 
Return on Equity (ROE) = Net income/Shareholders' equity

Price per Earnings Ratio $(\mathrm{PE})=$ Market value per share/Earnings per share

Debt per equity ratio $(\mathrm{D} / \mathrm{E})=$ Total liabilities/ Shareholders' equity

Earnings per share $($ EPS $)=$ Net income - Dividends on preferred stock/Average shares outstanding

7.1 Time frame and performance measure

The discussion on the performance of BCC was split into two; short run and long run. For the short run, performance was viewed on a yearly basis from 1996 till 2005. For this purpose, ROE was used (Wet and Toit, 2006; Sun and Tong, 2002). The effect of the long run involved three different intervals, a 3-year, 5-year and 10-year over the period 1996-2005. The details are given below. Table 1 shows a short run period ranging from P1 to P10 over the period 1996 to 2005. Table 2 shows a long run performance evaluation involving the period of 3,5 and 10 years.

Insert Table 1, Table 2 Here.

\section{Analyses and Results}

Before we move further, let us quickly take a look at the time series analysis of some of the performance indicators of BCC from P1 to P10 as shown in Figure 1 and 2.

Insert Figure 1, Figure 2 Here

Table 3 below presents descriptive statistics involving mean, standard deviation, minimum and maximum score of ROE over the 10-year period. Five out of ten mean score of ROE were registered in negative. It seemed most Bumiputera companies faced a major setback during the period 1998 to 2001.

Insert Table 3 Here

Table 4 below shows the results of the Wilcoxon Signed Ranks Test using ROE as a performance measure on a yearly basis over the 10-year period. Based on the results, significant z-scores were obtained only in the first 4 years. Thus, it seemed ROE of the Bumiputera Companies significantly dropped from 1996 to 1999. Hence, significant periodical dismal performance on a yearly basis (short tern effect) of the Bumiputera Companies could be traced in the first four years but then, they failed to show an upward trend in their performance till year 2005.

\section{Insert Table 4 Here}

Table 5 below shows the results of the Wilcoxon Signed Ranks Test using ROE as a performance measure with three intervals ( 3,5 and 10 years) over the 10 -year period. Based on the results, significant $z$-scores were obtained for all the three intervals. Thus, the highly significant long run effect on their performance can not be denied in the case of Bumi companies. Hence, Bumiputera Companies registered a dismal performance in the long run as compared to

\section{Insert Table 5 Here}

\section{Discussions and Conclusions}

Undoubtedly, Bumiputera- Controlled Companies (BCCs) were badly hit by the 1997 financial crisis. Though they managed to rebound after 2002 however, there was no significant improvement in the aftermath of the crisis period. This could relate BCCs to some fundamental problems as most firms were dependent on projects which were very much sensitive to financial stability of the country. It could be due to the fundamental aspects of the financial policy and decisions adopted by BCCs prior to the crisis. As financial decision involves both investment and financing decisions, it was argued that mis-matching issue in financing decisions was one of the major causes as to why not many companies really got off the ground in the aftermath of the 1997 financial crisis. For instance, short term financing was used for long term investment, so when faced with the crisis, companies had to pay back their debts in a short run but the returns could only be generated in a long run. It is quite difficult to prove over whether BCCs dealt with this problem, however, it can be pointed out that there must be some lessons to learn relating to their dismal performance especially from year 2000 to 2005 .

Obviously, BCCs were unable to generate sufficient returns for the shareholder as quite a number of them were relatively highly geared and therefore they tended to have high financial leverage. As a result, the market value started dropping due to the risk factor. Thus, it will be more fruitful for all BCCs in particular to go back to basic practices where the top level management (both top managers and board members) is ensure that its financial decisions are to be fundamentally sound. In fact, shareholder value appreciation is essentially important for long term survival. 


\section{Limitations}

The limitations of this study must be addressed here. Firstly, this study considered a relatively small sample size due to the strict requirements adopted in the selection process, thus argument on biasness can not be avoided. Secondly, the differences in the financial year end of the companies as well as the different accounting treatments could have affected the consistency of the ROE calculation and other performance measures or indicators. There were no primary data used to verify on the equity ownership by Bumiputeras of each company selected. Moreover, as the definition of Bumiputera companies is quite complicated and ambiguous, there could be a possibility of including government- linked companies or companies owned by ethnic-based political parties. Lack of literature on Bumi companies is also said to be another constraint in justifying and synthesizing the findings in this paper.

\section{Future Studies}

Future studies can take place by enlarging the sample size of Bumiputera-Controlled Companies and perform a comparative study against Non-Bumiputera-Controlled Companies in the last three decades. This study should involve both primary and secondary data for producing meaningful empirical findings. As a result, more insightful information could be derived from this kind of study particularly on the financial fundamentals adopted by these two groups of companies.

\section{References}

Bhagat, S. and Black, B. (2002). The non-correlation between board independence and long-term firm performance. Journal of Corporation Law, 27(2), 231.

Bris, A., Koskinen, Y. and Pons, V. (2004). Corporate financial policies and performance around currency crisis. Journal of Business, 7(4), 749-795.

Clayton, M. J. and Qian, Y. (2004). Wealth Gains From Tracking Stocks: Long-Run Performance And Ex-Date Returns. Financial Management, 33(3), 83.

Dev, P., George, S. V. and Mohamad, A. (2006). Government public policy, regulatory intervention and their impact on IPO under pricing: The case of Malaysian IPO's. Journal of Small Business Management, 44(1), 81-98.

Hou, O. and Chuang, S. (2007). CEO turnover, board chairman turnover, the key determinants: Empirical study on Taiwan listed company. The Business Review, 7(2), 129.

Hsu, C. and Boggs, D. J. (2003). Internationalization and performance: Traditional measures and their decomposition. Multinational Business Review, 11(3), 23-49.

How, J., Jelic, R., Saadouni, B. and Verhoeven, P. (2007). Share allocations and performance of KLSE second board IPOs. Pacific-Basin Finance Journal, 15(3), 292-314.

Meuse, K. P. De., Bergmann, T. J., Vanderheiden, P. A. and Roraff, C. E. (2004). New evidence regarding organizational downsizing and a firm's financial performance: A long-term analysis. Journal of Managerial Issues, 16(2), 155-177.

Murray, A. I. (1989). Top management group heterogeneity and firm performance. Strategic Management Journal, $10,125$.

Rahman, R. A. and Haniffa, R. M. (2005). The effect of role duality on corporate performance in Malaysia. Corporate Ownership and Control, 2(2), 40-47.

Sun, Q. and Tong, W. H. S. (2002). Malaysia privatization: A comprehensive study. Journal of Financial Management, 79-105.

Viani, B. E. (2004). Private control, competition and the performance of telephone firms in less developed countries. International Journal of the Economics of Business, 11(2), 217-240.

Westhead, P. and Howorth, C. (2006). Ownership and management issue associated with family firm performance and company objectives. Family Business Review, 19(4), 301.

Wet, J. H. v. H. de and Toit, E. du. (2007). Return on equity: A popular, but flawed measure of corporate financial performance. S. Afr. Journal of Business Management, 38(1), 59-69.

Yatim, Kent, P. and Clarkson, P. (2006). Governance structures, ethnicity, and audit fees of Malaysian listed firms. Managerial Auditing Journal, 21(7), 757-782.

Yatim, P., Pamela, K. and Peter, C. (2006). The Malaysian market for audit services: Ethnicity, multinational companies and auditor choice. Managerial Auditing Journal, 21(7), 702-723. 


\section{Note $s$}

Note 1. Source taken from http://en.wikipedia.org/wiki/Bumiputra

Note 2. Source from listing procedures and requirements: http://www.sc.com.my/eng/html/resources/discussion/PNS2.pdf

Note 3. Sources taken from the Asian Economic Review, 3rd Quarter 2000: http:/www.jri.co.jp/english/thinktank/research/aer/2000/AERe200003malaysia.html

\section{Appendix 1: List of Bumiputera-Controlled Companies}

\begin{tabular}{|c|c|}
\hline No & Company Name \\
\hline 1 & Advance Synergy Berhad \\
\hline 2 & Affin Holdings Berhad \\
\hline 3 & Ammb Holdings Berhad \\
\hline 4 & Antah Holdings Berhad \\
\hline 5 & Boustead Holdings Berhad \\
\hline 6 & Cement Industries Of Malaysia Berhad \\
\hline 7 & Damansara Realty Berhad \\
\hline 8 & Edaran Otomobil Nasional Berhad \\
\hline 9 & Far East Holdings Berhad \\
\hline 10 & Golden Plus Holdings Berhad \\
\hline 11 & Gopeng Berhad \\
\hline 12 & Integrated Logistics Berhad \\
\hline 13 & Kfc Holdings (Malaysia) Bhd \\
\hline 14 & Kulim (Malaysia) Berhad \\
\hline 15 & Land \& General (Holdings) Berhad \\
\hline 16 & Landmarks Berhad \\
\hline 17 & Malakoff Berhad \\
\hline 18 & Malaysian Airline System Berhad \\
\hline 19 & Menang Corporation Berhad \\
\hline 20 & Mulpha International Berhad \\
\hline 21 & Nam-Fatt Berhad \\
\hline 22 & Panglobal (Equities) Berhad \\
\hline 23 & Perusahaan Sadur Timah M'sia (Perstima) Bhd \\
\hline 24 & Rashid Hussain Berhad \\
\hline 25 & Spk-Sentosa Corporation Berhad \\
\hline 26 & Tdm Berhad \\
\hline 27 & (Syarikat) Telekom Malaysia Berhad \\
\hline 28 & Tenaga Nasional Berhad \\
\hline 29 & The New Straits Times Press Berhad \\
\hline 30 & Time Engineering Berhad \\
\hline 31 & Tradewinds (M) Berhad \\
\hline 32 & Uac Berhad \\
\hline 33 & Worldwide Holdings Berhad \\
\hline
\end{tabular}


Table 1. Short run period

\begin{tabular}{|l|l|l|}
\hline Year & Period & Pair \\
\hline 1996 & P1 & - \\
\hline 1997 & P2 & Pair 1 \\
\hline 1998 & P3 & Pair 2 \\
\hline 1999 & P4 & Pair 3 \\
\hline 2000 & P5 & Pair 4 \\
\hline 2001 & P6 & Pair 5 \\
\hline 2002 & P7 & Pair 6 \\
\hline 2003 & P8 & Pair 7 \\
\hline 2004 & P9 & Pair 8 \\
\hline 2005 & P10 & Pair 9 \\
\hline
\end{tabular}

Table 2. Long term period

\begin{tabular}{|c|c|}
\hline Period & Pair \\
\hline P1-P3 & Pair 1 \\
\hline P1-P5 & Pair 2 \\
\hline P1-P10 & Pair 3 \\
\hline
\end{tabular}

Table 3. Descriptive Statistics

\begin{tabular}{|l|r|r|r|r|r|}
\hline & $\mathrm{N}$ & \multicolumn{1}{c|}{ Mean } & \multicolumn{1}{c|}{ Std. Deviation } & \multicolumn{1}{c|}{ Minimum } & \multicolumn{1}{c|}{ Maximum } \\
\hline period1 & 33 & 10.7686 & 6.69160 & .73 & 30.35 \\
period2 & 33 & 1.1435 & 15.84819 & -40.85 & 26.51 \\
period3 & 33 & -31.2115 & 100.90789 & -561.30 & 22.21 \\
period4 & 33 & -5.8803 & 29.91881 & -112.98 & 27.09 \\
period5 & 33 & -3.7737 & 19.07182 & -48.35 & 24.67 \\
period6 & 33 & -2.6782 & 55.50238 & -229.06 & 167.80 \\
period7 & 33 & 2.0119 & 14.61255 & -67.66 & 18.64 \\
period8 & 33 & 2.3428 & 19.74107 & -99.98 & 16.91 \\
period9 & 33 & 3.4363 & 16.66388 & -81.91 & 18.39 \\
period10 & 33 & -1.9370 & 32.36107 & -157.36 & 26.22 \\
\hline
\end{tabular}


Table 4. Wilcoxon Signed Ranks Test - Short Term Performance

\begin{tabular}{|c|c|c|c|c|c|}
\hline Period & Details & $\mathrm{N}$ & Mean Rank & Sum of Ranks & Z-score/Sig \\
\hline $\begin{array}{c}\text { Period } 2-\text { Period } 1 \\
\text { Pair } 1\end{array}$ & $\begin{array}{c}\text { Negative } \\
\text { Ranks } \\
\text { Positive Ranks } \\
\text { Ties } \\
\text { Total }\end{array}$ & $\begin{array}{c}24 \\
9 \\
0 \\
33\end{array}$ & $\begin{array}{l}20.13 \\
8.67\end{array}$ & $\begin{array}{c}483.00 \\
78.00\end{array}$ & $-3.618^{* \star}$ \\
\hline $\begin{array}{c}\text { Period } 3-\text { Period } 2 \\
\text { Pair } \mathbf{2}\end{array}$ & $\begin{array}{c}\text { Negative } \\
\text { Ranks } \\
\text { Positive Ranks } \\
\text { Ties } \\
\text { Total }\end{array}$ & $\begin{array}{c}7 \\
1 \\
33\end{array}$ & $\begin{array}{l}18.16 \\
10.57\end{array}$ & $\begin{array}{c}454.00 \\
74.00\end{array}$ & $-3.553^{* *}$ \\
\hline $\begin{array}{c}\text { Period } 4 \text { - Period } 3 \\
\text { Pair } \mathbf{3}\end{array}$ & $\begin{array}{c}\text { Negative } \\
\text { Ranks } \\
\text { Positive Ranks } \\
\text { Ties } \\
\text { Total }\end{array}$ & $\begin{array}{c}10 \\
22 \\
1 \\
33\end{array}$ & $\begin{array}{l}13.50 \\
17.86\end{array}$ & $\begin{array}{l}135.00 \\
393.00\end{array}$ & $-2.412^{*}$ \\
\hline $\begin{array}{c}\text { Period } 5-\text { Period } 4 \\
\text { Pair } 4\end{array}$ & $\begin{array}{c}\text { Negative } \\
\text { Ranks } \\
\text { Positive Ranks } \\
\text { Ties } \\
\text { Total }\end{array}$ & $\begin{array}{c}12 \\
2 \\
33\end{array}$ & $\begin{array}{l}16.05 \\
15.92\end{array}$ & $\begin{array}{l}305.00 \\
191.00\end{array}$ & -1.117 \\
\hline $\begin{array}{c}\text { Period } 6-\text { Period } 5 \\
\text { Pair } 5\end{array}$ & $\begin{array}{c}\text { Negative } \\
\text { Ranks } \\
\text { Positive Ranks } \\
\text { Ties } \\
\text { Total }\end{array}$ & $\begin{array}{c}14 \\
18 \\
1 \\
33\end{array}$ & $\begin{array}{l}17.07 \\
16.06\end{array}$ & $\begin{array}{l}239.00 \\
289.00\end{array}$ & -0.467 \\
\hline $\begin{array}{c}\text { Period } 7 \text { - Period } 6 \\
\text { Pair } 6\end{array}$ & $\begin{array}{c}\text { Negative } \\
\text { Ranks } \\
\text { Positive Ranks } \\
\text { Ties } \\
\text { Total }\end{array}$ & $\begin{array}{c}16 \\
1 \\
33\end{array}$ & $\begin{array}{l}17.19 \\
15.81\end{array}$ & $\begin{array}{l}275.00 \\
253.00\end{array}$ & -0.206 \\
\hline $\begin{array}{c}\text { Period } 8-\text { Period } 7 \\
\text { Pair } 7\end{array}$ & $\begin{array}{c}\text { Negative } \\
\text { Ranks } \\
\text { Positive Ranks } \\
\text { Ties } \\
\text { Total }\end{array}$ & $\begin{array}{c}21 \\
1 \\
33\end{array}$ & $\begin{array}{l}18.73 \\
15.33\end{array}$ & $\begin{array}{l}206.00 \\
322.00\end{array}$ & -1.085 \\
\hline $\begin{array}{c}\text { Period } 9 \text { - Period } 8 \\
\text { Pair } 8\end{array}$ & $\begin{array}{c}\text { Negative } \\
\text { Ranks } \\
\text { Positive Ranks } \\
\text { Ties } \\
\text { Total }\end{array}$ & $\begin{array}{c}14 \\
17 \\
2 \\
33\end{array}$ & $\begin{array}{l}13.57 \\
18.00\end{array}$ & $\begin{array}{l}190.00 \\
306.00\end{array}$ & -1.137 \\
\hline $\begin{array}{c}\text { Period } 10-\text { Period } 9 \\
\text { Pair } 9\end{array}$ & $\begin{array}{c}\text { Negative } \\
\text { Ranks } \\
\text { Positive Ranks } \\
\text { Ties } \\
\text { Total } \\
\end{array}$ & $\begin{array}{c}14 \\
2 \\
33 \\
\end{array}$ & $\begin{array}{l}18.12 \\
13.43\end{array}$ & $\begin{array}{l}308.00 \\
188.00\end{array}$ & -1.176 \\
\hline
\end{tabular}

* Significant at $0.05,{ }^{* *}$ Significant at 0.01 
Table 5. Wilcoxon Signed Ranks Test - Long Term Performance

\begin{tabular}{|c|c|c|c|c|c|}
\hline Period & Details & $\mathrm{N}$ & Mean Rank & Sum of Ranks & Z-score/Sig \\
\hline \multirow[t]{4}{*}{$\begin{array}{c}\text { Period } 3-\text { Period } 1 \\
\text { Pair } 1\end{array}$} & $\begin{array}{c}\text { Negative } \\
\text { Ranks }\end{array}$ & 29 & 17.97 & 521.00 & $-4.297 * *$ \\
\hline & Positive Ranks & 4 & 10.00 & 40.00 & \\
\hline & Ties & 0 & & & \\
\hline & Total & 33 & & & \\
\hline \multirow[t]{4}{*}{$\begin{array}{c}\text { Period } 5-\text { Period } 1 \\
\text { Pair } \mathbf{2}\end{array}$} & $\begin{array}{c}\text { Negative } \\
\text { Ranks }\end{array}$ & 29 & 17.45 & 506.00 & $-4.029^{* *}$ \\
\hline & Positive Ranks & 4 & 13.75 & 55.00 & \\
\hline & Ties & 0 & & & \\
\hline & Total & 33 & & & \\
\hline \multirow[t]{4}{*}{$\begin{array}{c}\text { Period } 10-\text { Period } 1 \\
\text { Pair } 3\end{array}$} & $\begin{array}{c}\text { Negative } \\
\text { Ranks }\end{array}$ & 23 & 19.70 & 453.00 & $-3.082 * *$ \\
\hline & Positive Ranks & 10 & 10.80 & 108.00 & \\
\hline & Ties & 0 & & & \\
\hline & Total & 33 & & & \\
\hline
\end{tabular}

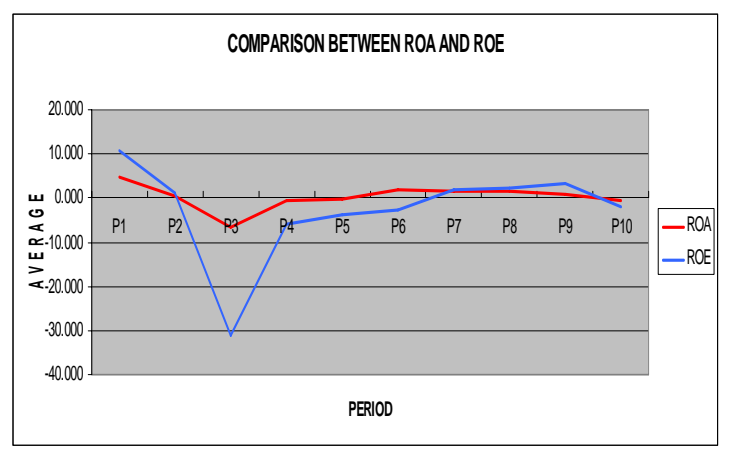

Figure 1. Comparison between ROA and ROE

Figure 1 shows that ROA of Bumiputera-controlled companies started at an average of 4.617 per cent in 1996 but dropped below zero in 1997 until 1998 due to the Asian financial crisis. Then remained constant between 0 and 2 per cent till 2004 (P9) but then registered a negative figure in 2005. On the other hand, the Return on Equity (ROE) also shows the same trend, though started at a higher figure (10.769 per cent) but I took a steep dive (about -30 per cent) in 1997 and 1998 (P2 and P3) but registered a positive return only in 2002 onwards. However, ROE was back to negative in 2005 .

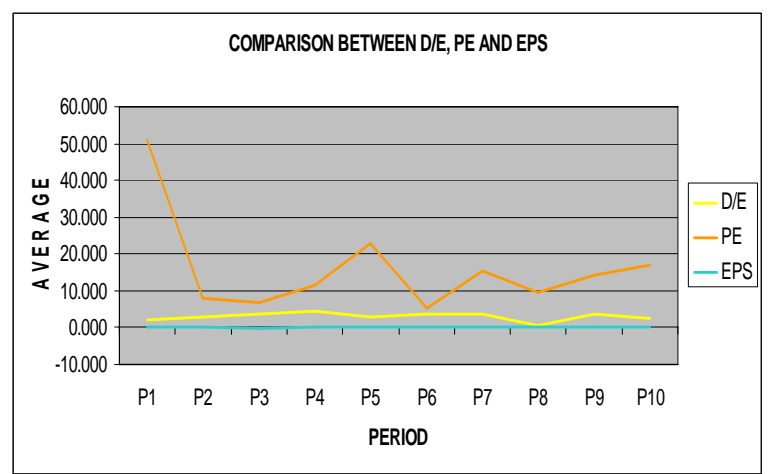

Figure 2. Comparison among PE, D/E and EPS

Figure 2 indicates that debt - Equity (D/E) ratio was not highly fluctuative (below 4 times) as compared to PE ratio where the fluctuation was in range of 5 to 50 times throughout the 10 year period. Meanwhile, EPS seemed to be at an average of slightly above 0 during the 10 year period. 